\title{
Review
}

\section{Pulmonary Diseases in Refugees and Migrants in Europe}

\author{
Ioana D. Olaru ${ }^{a}$ Steven Van Den Broucke ${ }^{b}$ Andrew J. Rosser ${ }^{c}$ \\ Helmut J.F. Salzer ${ }^{d}$ Gerrit Woltmann $^{\mathrm{e}}$ Emmanuel Bottieau $^{\mathrm{b}}$ \\ Christoph Lange ${ }^{d, f, g}$
}

a Department of Clinical Research, London School of Hygiene and Tropical Medicine, London, UK;

${ }^{b}$ Department of Clinical Sciences, Institute of Tropical Medicine, Antwerp, Belgium; ' Department of Infection, University Hospital Southampton NHS Foundation Trust, Southampton, UK; ${ }^{d}$ Division of Clinical Infectious Diseases, Research Center Borstel, Borstel, Germany; ${ }^{e}$ Respiratory Biomedical Research Centre, Institute for Lung Health, Department of Infection Immunity and Inflammation, University of Leicester, Leicester, UK; ${ }^{\mathrm{f}}$ International Health/Infectious Diseases, University of Lübeck, Lübeck, Germany; ${ }^{9}$ Department of Medicine, Karolinska Institute, Stockholm, Sweden

\section{Keywords}

Migration · Asylum seekers · Tropical diseases · Chronic diseases

\begin{abstract}
More than 2 million people fleeing conflict, persecution, and poverty applied for asylum between 2015 and 2016 in the European Union. Due to this, medical practitioners in recipient countries may be facing a broader spectrum of conditions and unusual presentations not previously encountered, including a wide range of infections with pulmonary involvement. Tuberculosis is known to be more common in migrants and has been covered broadly in other publications. The scope of this review was to provide an overview of exotic infections with pulmonary involvement that could be encountered in refugees and migrants and to briefly describe their epidemiology, diagnosis, and management. As refugees and migrants travel from numerous countries and continents, it is important to be aware of the various organisms that might cause disease according to the country of
\end{abstract}

origin. Some of these diseases are very rare and geographically restricted to certain regions, while others have a more cosmopolitan distribution. Also, the spectrum of severity of these infections can vary from very benign to severe and even life-threatening. We will also describe infectious and noninfectious complications that can be associated with HIV infection as some migrants might originate from high HIV prevalence countries in sub-Saharan Africa. As the diagnosis and treatment of these diseases can be challenging in certain situations, patients with suspected infection might require referral to specialized centers with experience in their management. Additionally, a brief description of noncommunicable pulmonary diseases will be provided.

(c) 2018 S. Karger AG, Basel

\section{Introduction}

Ohm's law $(\mathrm{I}=\mathrm{V} / \mathrm{R})$ not only applies to electrical currents, but describes very well the forces of human migration (I) following gradients (V) despite obstacles (R).

\section{KARGER}

(C) 2018 S. Karger AG, Basel

E-Mail karger@karger.com

www.karger.com/res
Ioana D. Olaru

Department of Clinical Research

London School of Hygiene and Tropical Medicine

Keppel Street, London WC1E 7HT (UK)

E-Mail ioana-diana.olaru@lshtm.ac.uk 
Fig. 1. Cumulative asylum applications for 2015 and 2016. The country shading represents the number of asylum applications per 100,000 population. The circles represent the absolute number of applications per country. The figures within the circles are the numbers in thousands (Source: Eurostat [3]).

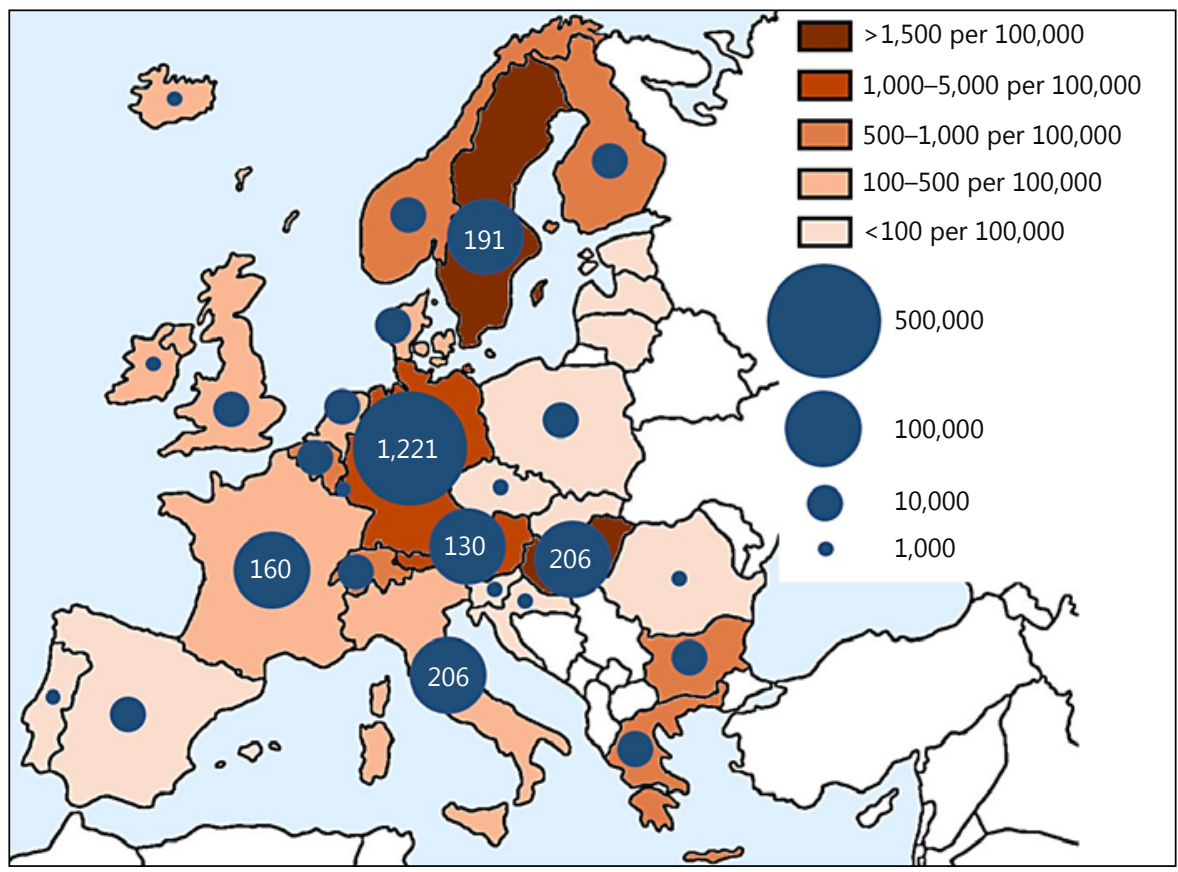

Poverty, war, climate change, and sometimes missing or inadequate healthcare provision are driving people to leave their homes and to move to places that provide a prospect of better living conditions, security, or simply a chance to survive a potentially life-threatening disease. Approximately 22.5 million people worldwide were forced to leave their country due to persecution, conflict, or violence in the year 2016 [1]. Following political instability and civil war in countries like Syria, Afghanistan, or Iraq, or as a consequence of poverty in countries of the Balkan region or many African countries, large numbers of refugees have been seeking asylum in highincome European countries in recent years. Despite severe hardships during travel, risking their lives during passage across the Northern African desert, the Mediterranean Sea, as well as other obstacles, large numbers of people have applied for asylum in what could be considered the largest wave of migration to Europe since the end of World War II [2]. 1.26 million people applied for asylum in the countries of the European Union in the year 2015, and another 1.20 million asylum seekers were registered in 2016 [3]. Of those, almost 700,000 were Syrian refugees. More than $80 \%$ of the first-time asylum seekers in countries of the European Union in 2016 were $<35$ years of age, and 63,300 asylum applications were from unaccompanied minors [3]. The number of asylum applications for individual countries is shown in Figure 1.
Most asylum seekers, refugees, and migrants come from countries where certain infectious diseases are more prevalent, while in Western Europe the same infectious diseases might be rare or nonexistent. Taking into account this large number of refugees and migrants over recent years, European physicians and pulmonologists will have to consider a wider range of conditions when dealing with such patients, including diseases encountered in their countries of origin (Table 1). Screening for tuberculosis has been widely implemented to identify active cases in refugees [4]. However, tuberculosis in migrants and refugees has extensively been described elsewhere $[5,6]$ and is beyond the scope of this review. The aim of this review was to provide an overview of pulmonary diseases that might be encountered in refugees and migrants to high-income European countries. Due to the number and diversity of infectious organisms that have the potential to cause pulmonary disease, we will only focus on a few of these organisms which are either more common or more likely to pose problems in clinical practice.

\section{Bacterial Diseases}

\section{Antimicrobial Resistance}

Migrants are especially vulnerable to the acquisition of drug-resistant organisms and facilitating their subsequent spread [7]. Studies of refugees arriving in high-income 
Table 1. Infectious diseases to be considered in asylum seekers according to country of origin

\begin{tabular}{lll}
\hline $\begin{array}{l}\text { Country } \\
\text { of origin }\end{array}$ & $\begin{array}{l}\text { Number of asylum } \\
\text { seekers in the EU } \\
\text { (thousands) }\end{array}$ & Infectious diseases that should be considered \\
\hline Syria & 707.6 & CE, tuberculosis \\
Afghanistan & 368.0 & tuberculosis \\
Iraq & 254.9 & tuberculosis, CE \\
Albania & 100.2 & CE \\
Pakistan & 97.8 & tuberculosis \\
Kosovo & 84.1 & CE \\
Nigeria & 78.9 & tuberculosis, HIV, Strongyloides stercoralis, schistosomiasis \\
Eritrea & 68.6 & tuberculosis, HIV, Strongyloides stercoralis, schistosomiasis \\
Iran & 67.9 & tuberculosis, CE \\
Russia & 49.8 & tuberculosis (including MDR-TB), HIV, CE (regional) \\
Somalia & 41.1 & tuberculosis, Strongyloides stercoralis \\
Ukraine & 34.5 & tuberculosis (including MDR-TB), HIV \\
\hline
\end{tabular}

CE, cystic echinococcosis; MDR-TB, multidrug-resistant tuberculosis. ${ }^{1}$ Source: Eurostat [3] for 2015 and 2016.

countries have noted a high prevalence of drug-resistant tuberculosis [8], infections with antibiotic-resistant Enterobacteriaceae $[9,10]$, and colonization with antibioticresistant bacteria [11]. Refugees seem to be particularly at risk in part due to the elevated levels of antimicrobial resistance in their countries of origin and enhanced acquisition due to failing infrastructure and insanitary conditions [12]. Although refugees appear to be a high-risk group, whether routine preemptive isolation and screening should be recommended and would be worthwhile is not as yet resolved [13]. The risk of colonization with drug-resistant organisms should be assessed in all patients admitted to healthcare facilities taking into account areas visited, patient history, and other risk factors such as previous hospitalization. Although colonization and infections due to multidrug-resistant organisms represent an issue of the highest importance, most healthcare facilities in high-income European countries should ideally have protocols in place for patient screening and infection prevention. These would enable healthcare workers to rapidly identify and manage patients with colonization/infections caused by multidrug-resistant organisms.

\section{Melioidosis}

A rarer bacterial infection is melioidosis caused by Burkholderia pseudomallei. It is prevalent in tropical and subtropical regions, most commonly Northern Australia and Southeast Asia [14], although cases in Africa [15] and the Americas have been reported [16]. Melioidosis principally affects those in direct contact with muddy water

Pulmonary Diseases in Refugees and Migrants in Europe and soil and is predominantly acquired through inhalation, ingestion, or inoculation [17]. Older immunosuppressed adults, particularly those with diabetes mellitus or alcoholism, are particularly at risk of infection [18]. In temperate regions, infections are typically imported by migrants and travelers [19]. Incubation periods may be as short as 1-3 weeks [20], but latent infections with recrudescence many years later are recognized [21]. Patients characteristically present with pneumonia, genitourinary and cutaneous presentations being less common [18]. Notably, many patients become septicemic [17]. The diagnosis is typically confirmed by the culture of $B$. pseudomallei from clinical samples including blood, respiratory tract secretions, and abscess pus. Serology and molecular methods are also used [22]. Localized disease may be treated with doxycycline; however, severe disease requires intravenous treatment with ceftazidime or meropenem for several weeks followed by oral consolidation with co-trimoxazole and doxycycline for up to 20 weeks [23]. Currently, there is no vaccine in clinical use; prevention is best achieved by avoiding contact with contaminated water or soil, particularly by wearing shoes [19].

\section{Viral Infections}

\section{Influenza}

Influenza $\mathrm{A}, \mathrm{B}$, and $\mathrm{C}$ viruses cause predominately pulmonary infections in humans, with influenza $\mathrm{A}$ and $\mathrm{B}$ responsible for seasonal outbreaks that afflict up to $15 \%$ of 
Table 2. HIV and lung involvement

\begin{tabular}{|c|c|}
\hline Infections & $\begin{array}{l}\text { tuberculosis } \\
\text { nontuberculous mycobacteria } \\
\text { histoplasmosis } \\
\text { coccidioidomycosis } \\
\text { paracoccidioidomycosis } \\
\text { Pneumocystis jirovecii } \\
\text { bacterial pneumonia } \\
\text { Rhodococcus equi } \\
\text { Nocardia spp. } \\
\text { pulmonary cryptococcosis } \\
\text { cytomegalovirus }\end{array}$ \\
\hline $\begin{array}{l}\text { Interstitial lung } \\
\text { diseases }\end{array}$ & $\begin{array}{l}\text { lymphocytic interstitial pneumonia } \\
\text { nonspecific interstitial pneumonia } \\
\text { cryptogenic organizing pneumonia } \\
\text { hypersensitivity pneumonitis } \\
\text { sarcoidosis }\end{array}$ \\
\hline Vascular diseases & HIV-associated PAH \\
\hline Malignancies & $\begin{array}{l}\text { Kaposi sarcoma } \\
\text { non-Hodgkin lymphoma } \\
\text { Hodgkin lymphoma } \\
\text { multicentric Castleman disease } \\
\text { primary lung cancer }\end{array}$ \\
\hline $\begin{array}{l}\mathrm{HIV} \text {-associated } \\
\text { airway diseases }\end{array}$ & $\begin{array}{l}\text { chronic obstructive pulmonary disease } \\
\text { asthma } \\
\text { bronchiectasis }\end{array}$ \\
\hline
\end{tabular}

$\mathrm{PAH}$, pulmonary arterial hypertension.

the world's population annually [24]. Migrants do not specifically represent a risk of spreading influenza to receiving countries [25]. Nonetheless, migrants are more susceptible to influenza in part due to lower levels of vaccine coverage $[26,27]$. Infection may be transmitted by droplet, aerosol, or contact [28]. The respiratory features of influenza range from asymptomatic infection to severe pneumonia [29]. Those patients who are hospitalized with proven or suspected infection should be treated with neuraminidase inhibitors such as oseltamivir or zanamivir [30]. Prevention measures include hand sanitization, vaccination, and possibly face masks [31].

\section{Middle East Respiratory Syndrome Coronavirus}

The Middle East respiratory syndrome coronavirus (MERS-CoV) was first identified in Saudi Arabia in 2012 [32]. It is thought that most cases occur on the Arabian Peninsula and/or are epidemiologically linked to this region [33]. Dromedary camels are thought to be the natural host for MERS-CoV, which may be transmitted to humans by close contact with the animals [34]. Human-to- human transmission has occurred mainly in healthcare settings; thus, control measures should focus on rapid case identification and strict infection control practices to prevent onward transmission [35]. The average incubation period is 5 days (range 2-13 days) [36], and any patient with fever and pneumonia or acute respiratory distress syndrome with onset within 14 days of travel to an endemic area should be considered a patient under investigation for MERS-CoV [37]. The clinical spectrum of disease ranges in severity from asymptomatic infection to severe pneumonia requiring mechanical ventilation [32]. Patients particularly at risk of severe disease include those with chronic kidney disease requiring hemodialysis, those with diabetes mellitus, or those aged $>50$ years [38]. MERS-CoV cases are confirmed by detection of viral RNA in clinical samples or by demonstration of seroconversion [39]. Treatment is primarily supportive, with virus-directed therapies currently deemed investigational [40].

\section{HIV Infection and the Lung}

An estimated 36.7 million people are living with HIV worldwide, with $>70 \%$ of them residing in low- and middle-income countries [41]. HIV infection can be associated with a number of infectious and noninfectious pulmonary complications (Table 2). This section does not aim to describe them in detail, but rather to provide an overview of conditions that pulmonologists should be aware of when treating HIV-infected patients. Also, it is beyond the scope of this paper to describe the relationship between HIV and tuberculosis, which cause substantial morbidity and mortality particularly in low-income settings. It is widely known that HIV infection is associated with an increased risk of tuberculosis, with people living with HIV accounting for $10 \%$ of the new tuberculosis cases reported in 2016 [42]. Other opportunistic infections associated particularly with advanced HIV infection are Pneumocystis jirovecii pneumonia, disseminated histoplasmosis, and recurrent bacterial pneumonias [43].

With antiretroviral therapy scale-up and co-trimoxazole prophylaxis, there has been a decline in pulmonary infections and an increased survival of people living with HIV $[44,45]$. This is turn has led to an increased importance of chronic and noninfectious lung diseases. Noninfectious pulmonary conditions encountered in people living with HIV can be categorized into three main groups: interstitial lung diseases (ILDs), pulmonary vascular diseases, and malignancies.
Olaru/Van Den Broucke/Rosser/Salzer/ Woltmann/Bottieau/Lange 
Certain ILDs are more frequently encountered in people living with HIV. Before the widespread use of antiretroviral therapy, lymphocytic interstitial pneumonia in children and nonspecific interstitial pneumonia were more common, whereas now the spectrum of ILDs has changed towards cryptogenic organizing pneumonia, sarcoidosis, and hypersensitivity pneumonitis [46].

HIV-related pulmonary arterial hypertension (PAH) is included in group I of the updated classification of pulmonary hypertension [47]. It is estimated that the prevalence of PAH related to HIV is much higher than that in the general population [48]. According to a systematic review, the prevalence of PAH among HIV-infected individuals presenting with cardiovascular symptoms from Africa is as high as $14 \%$ [49], but the number of studies included was very small. Schistosomiasis (see below), which is independently associated with $\mathrm{PAH}[47,50]$, and other concurrent chronic lung diseases could also contribute to an increased burden of PAH in low-income settings [51]. The true prevalence of HIV-related PAH is however difficult to ascertain due to differences in methods used for establishing the diagnosis. Transthoracic echocardiography tends to overestimate the prevalence and cannot accurately evaluate pulmonary vascular pressures [46]. Patients with HIV-related PAH are likely to benefit from the same therapies as non-HIV patients [50]. However, physicians should note that there are drug interactions between phosphodiesterase type $\mathrm{V}$ inhibitors such as sildenafil and protease inhibitors [52].

HIV-related pulmonary malignancies can be classified as AIDS-defining of non-AIDS-defining. The former group includes Kaposi sarcoma and non-Hodgkin lymphoma. Pulmonary Kaposi sarcoma presents in patients with advanced HIV and usually has concomitant mucocutaneous involvement which can be helpful in establishing the diagnosis. During bronchoscopy, Kaposi sarcoma lesions appear as red or purple-colored; however, if located distally, they are not always visualized. Histologically, Kaposi sarcoma has characteristic spindle cells and high vascularization [46]. Treatment consists of antiretroviral therapy, which can lead to regression, or if this is not effective, additional chemotherapy and/or radiotherapy.

Primary lung cancer is 2.5 times more common in people living with HIV than in the general population [53] and carries a worse prognosis, possibly because patients tend to present with more advanced disease [54, 55].

HIV has also been shown to increase the risk of other pulmonary disorders, such as chronic obstructive pulmonary disease (COPD) [56] or bronchiectasis [57].

Pulmonary Diseases in Refugees and

Migrants in Europe

\section{Pulmonary Fungal Infections}

Tropical and Subtropical Systemic Endemic Mycoses

Histoplasmosis. Infection caused by Histoplasma capsulatum var. capsulatum is found worldwide, particularly in North, Central, and South America [58], but also in Southeast Asia and Africa [59]. In Africa it coexists with H. capsulatum var. duboisii [60]. The infection is rare in Europe and most cases are imported [59]. It is a dimorphic fungus that can lead to pulmonary infection after inhalation of microscopic fungal spores. At risk are people visiting caves infested by bats or people who are exposed during construction renovations, but it has also the ability to cause outbreaks [61]. Most infections are asymptomatic, but some individuals develop flu-like symptoms. Only a few, especially immunocompromised patients can develop severe disease and progressive pulmonary or disseminated infection. Acute respiratory symptoms with diffuse infiltrates on chest imaging are common presentations, but acute localized infiltrates, mediastinal lymphadenopathy, chronic cavitary pulmonary histoplasmosis, mediastinal syndromes (e.g., mediastinitis, fibrosis), broncholithiasis, or pulmonary nodules can also occur [58]. The diagnosis should be based on a combination of at least two diagnostic methods including histology, culture, antigen test, serology, or polymerase chain reaction [62]. The treatment depends on disease severity. Patients with mild to moderate pulmonary histoplasmosis and $<4$ weeks of symptoms do not benefit from antifungal treatment. In patients with symptoms $>4$ weeks, treatment with itraconazole $200-400 \mathrm{mg}$ for 6-12 weeks is recommended [63]. The treatment duration is extended to $18-24$ months in patients with chronic cavitary histoplasmosis. A lipid formulation of amphotericin B (3.0-5.0 mg/kg daily intravenously for 1-2 weeks) is recommended in patients with moderate to severe acute pulmonary histoplasmosis or in patients with progressive disseminated histoplasmosis, which can be switched to oral itraconazole after clinical improvement. Itraconazole prophylaxis with $200 \mathrm{mg}$ daily is recommended in HIV-positive patients with a CD4 cell count $<150$ cells $/ \mathrm{mm}^{3}$ in high endemic regions [63].

Paracoccidioidomycosis. Paracoccidioidomycosis is endemic in certain parts of South America, especially in Brazil [64]. Outdoor activities such as agriculture are risk factors for infection. Most infections are asymptomatic. Symptomatic disease can occur as an acute/subacute (juvenile) form, which usually presents with enlarged lymph nodes, hepatosplenomegaly, and/or cutaneous/mucosal lesions, but rarely with pulmonary manifestations. In con- 
trast, the chronic (adult) form often presents with severe pulmonary involvement, but other organs such as the central nervous system, bones, or the adrenal glands can also be involved. Severe infections are usually seen in immunocompromised patients. The radiological signs are apical pleural-pulmonary lesions and enlarged hilar lymph nodes. The diagnosis can be made after identification of yeast forms in tissue samples or by culturing. Patients with mild to moderate disease are usually treated with itraconazole $200 \mathrm{mg}$ daily for an average duration of 12 months [64]. Co-trimoxazole is recommended as an alternative treatment. Amphotericin B can be used for severe disease.

Talaromycosis. Talaromyces marneffei, previously known as Penicillium marneffei, is a dimorphic fungus endemic to Southeast Asia that causes severe infections in immunocompromised patients, especially in patients with HIV/AIDS, and has a mortality of up to $30 \%$ [65]. The clinical symptoms range from mild forms presenting with skin lesions to moderate disease with multiple organ involvement and severe disease including respiratory failure. The radiological appearance is characterized by reticulonodular or alveolar infiltrations with or without consolidation, which can be localized or disseminated. The diagnosis can be made by culture of clinical samples (e.g., skin biopsy, blood culture). Antifungal treatment includes itraconazole and amphotericin B. Recently, a large study reported a better outcome for amphotericin B compared to itraconazole [66].

\section{Other Fungal Infections}

Cryptococcosis. Apart from central nervous system involvement, Cryptococcus neoformans and Cryptococcus gattii can also cause pulmonary cryptococcosis [67]. Immunocompetent patients often stay asymptomatic or develop mild pneumonitis. There is no specific radiological pattern, but it frequently presents as solitary nodules, lobar infiltrates, and/or hilar and mediastinal lymphadenopathy. Disease severity strongly depends on the patient's immune status. The diagnosis is usually made by histology, fungal culture, and/or serum antigen test. Immunocompromised patients with pulmonary cryptococcosis should also be screened for central nervous system involvement by lumbar puncture with culture and antigen test of cerebrospinal fluid. Asymptomatic immunocompetent patients do not benefit from antifungal treatment. For focal pulmonary infiltrates, fluconazole $400 \mathrm{mg}$ daily for 6-12 month is recommended. However, patients with HIV infection and diffuse pulmonary cryptococcosis should be treated similarly to those with central nervous system diseases, using amphotericin B and flucyto- sine for a minimum of 2 weeks during the induction phase, followed by consolidation and maintenance with fluconazole for at least 12 months [68]. Alternative treatment includes other azoles such as itraconazole, voriconazole, posaconazole, or isavuconazole [69].

P. jirovecii Pneumonia. P. jirovecii is an opportunistic pathogen causing severe infections in immunocompromised patients. Interestingly, the disease dynamics differs between HIV and non-HIV cases. While the latter is an acute disease developing within days with high mortality, the disease shows a much slower progression in HIV/ AIDS patients [70]. Chest computed tomography usually shows symmetric ground glass opacities. Co-trimoxazole $15-20 \mathrm{mg} / \mathrm{kg}$ in four divided doses per day for 21 days is the treatment of choice. The dosage is calculated based on the trimethoprim component. In severe HIV-positive cases, adjunct corticosteroids are recommended. The role of corticosteroids in non-HIV patients remains unclear, with a recent meta-analysis showing no benefit [71], and they should not be prescribed routinely in patients with respiratory failure [72]. Alternative treatment regimens include pentamidine, primaquine + clindamycin, atovaquone, or dapsone + trimethoprim $[68,72]$.

Chronic Pulmonary Aspergillosis. Chronic pulmonary aspergillosis is found worldwide and is not restricted to the tropics. Pulmonary tuberculosis, which is more prevalent in low-income countries, is one of the most important risk factors for the development of chronic pulmonary aspergillosis $[73,74]$. The clinical presentation can vary considerably from asymptomatic to life-threating hemoptysis [75]. The diagnosis is made by a combination of radiological, clinical, and mycological criteria [76]. Beside an Aspergillus IgG antibody test from serum, bronchoscopy should be performed in all patients, depending on a risk/ benefit assessment to prove mycological evidence and to exclude alternative diagnoses [77]. Itraconazole (200 mg b.i.d.) or voriconazole (150-200 $\mathrm{mg}$ b.i.d.) for at least 6 months is the treatment of choice [76]. Surgery should be considered in patients with single aspergillomas. A multidisciplinary approach could improve the management and treatment outcome of these difficult-to-treat patients with chronic pulmonary aspergillosis [78].

\section{Parasitic Diseases with Pulmonary Involvement (Table 3)}

\section{Pleuropulmonary Amebiasis}

Entamoeba histolytica is a protozoan with a worldwide distribution, although it is by far more prevalent the trop-
Olaru/Van Den Broucke/Rosser/Salzer/ Woltmann/Bottieau/Lange 
Table 3. Overview of parasitic pulmonary infections in refugees: diagnosis and treatment

\begin{tabular}{llll}
\hline Disease & Causative organism & Diagnosis & Treatment \\
\hline $\begin{array}{l}\text { Cystic } \\
\text { echinococcosis }\end{array}$ & $\begin{array}{l}\text { Echinococcus } \\
\text { granulosus }\end{array}$ & $\begin{array}{l}\text { serology (IgG-ELISA); imaging } \\
\text { (X-ray, CT) }\end{array}$ & $\begin{array}{l}\text { albendazole } 400 \mathrm{mg} \text { b.i.d. (15 mg/kg/day if } \\
<60 \mathrm{~kg}) ; \text { surgical resection; watch and wait }\end{array}$ \\
\hline Amebiasis & $\begin{array}{l}\text { Entamoeba } \\
\text { histolytica }\end{array}$ & $\begin{array}{l}\text { stool microscopy (low sensitivity); } \\
\text { serology; antigen detection; PCR; } \\
\text { imaging }\end{array}$ & $\begin{array}{l}\text { metronidazole } 750 \mathrm{mg} \text { t.i.d. (7-10 days), } \\
\text { tinidazole } 800 \mathrm{mg} \text { t.i.d. ( } 5 \text { days); paromomycin } \\
25-35 \mathrm{mg} / \mathrm{kg} / \text { day divided into } 3 \text { doses (7 days) } \\
\text { or diloxanide furoate } 500 \mathrm{mg} \text { t.i.d. (10 days) or } \\
\text { iodoquinol } 650 \text { mg t.i.d. (20 days) to eradicate } \\
\text { intestinal infection; surgical drainage may } \\
\text { sometimes be needed }\end{array}$ \\
\hline
\end{tabular}

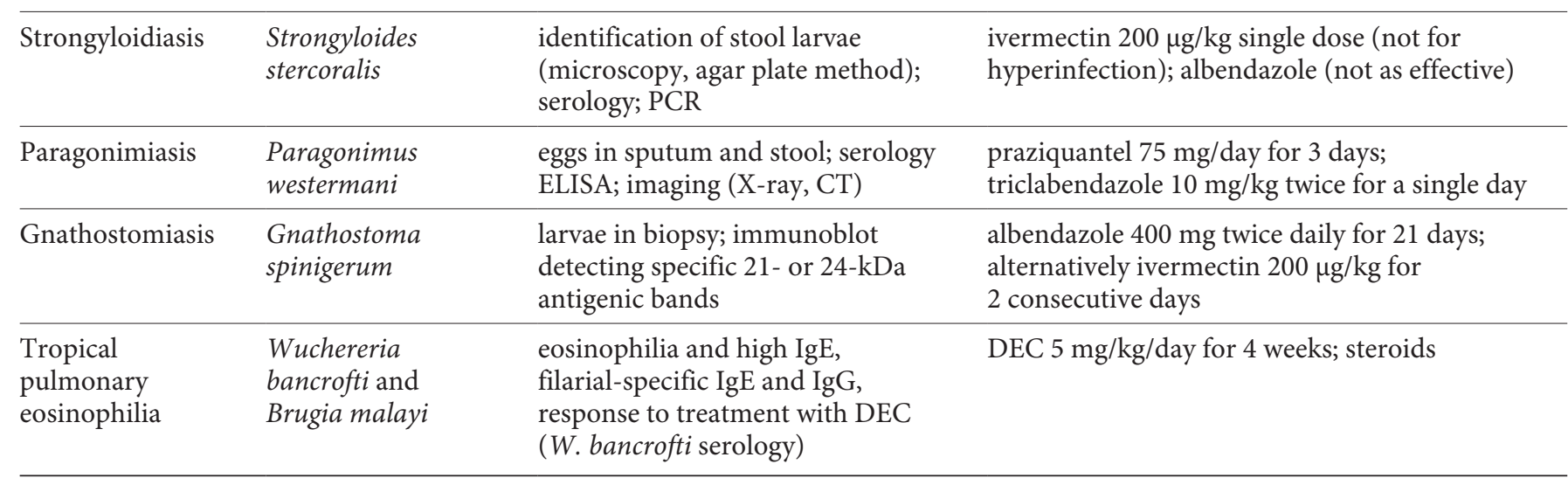

CT, computed tomography, DEC, diethylcarbamazine, ELISA, enzyme-linked immunosorbent assay, PCR, polymerase chain reaction.

ics. An estimated 104 million cases of E. histolytica infection occurred in 2010 [79]. Infection occurs by ingestion of contaminated food or water and can be asymptomatic or can lead to dysentery or less frequently to extraintestinal disease in $<1 \%$ of cases [80]. Pleuropulmonary infection is the second most common extraintestinal localization [81] and occurs usually by extension from a liver abscess. It can take the form of pneumonia, lung abscess, pleural effusion. and empyema or bronchohepatic fistula [82]. The clinical symptoms consist of fever, cough, and pleuritic chest pain and, if a bronchohepatic fistula develops, expectoration of "anchovy-sauce" pus [83]. Rightsided atelectasis and pleural effusions are the most common presentations [84], while elevation of the right diaphragm can be observed due to a hepatic abscess [83]. E. histolytica-specific antibody assays, antigen detection, or species-specific polymerase chain reaction are the most useful diagnostic tools for extraintestinal amebiasis [80]. The treatment consists of nitroimidazole followed by paromomycin or alternatively diloxanide furoate to eradicate intestinal carriage [80]. Disappearance of the lesions at imaging takes much longer than the relatively fast clinical recovery; this should not be considered as treatment failure.

\section{Cystic Echinococcosis}

Cystic echinococcosis (CE) is a neglected zoonotic disease caused by the larval stage of the cestode (tapeworm) Echinococcus granulosus. An estimated 188,000 new cases of CE occurred in 2010 globally [85]. CE has a worldwide distribution, but is more prevalent in regions of the Eastern Mediterranean, Northern Africa, Southern and Eastern Europe, southern South America, Central Asia, and parts of China. Its incidence can exceed 50 per 100,000 person-years in areas of high endemicity, with a prevalence of $5-10 \%$ in humans [86]. In high-income countries, CE is mostly an imported disease; however, it is endemic in some regions of Southeastern Europe [87].

Adult worms inhabit the small intestine of carnivores (canines, felids); eggs are passed with the feces and ingested by the intermediate hosts (sheep, cattle, horses, etc.). In the intermediate host, the larval stages develop into (hydatid) cysts and produce protoscolices which in turn develop into adult worms if ingested by the definitive 


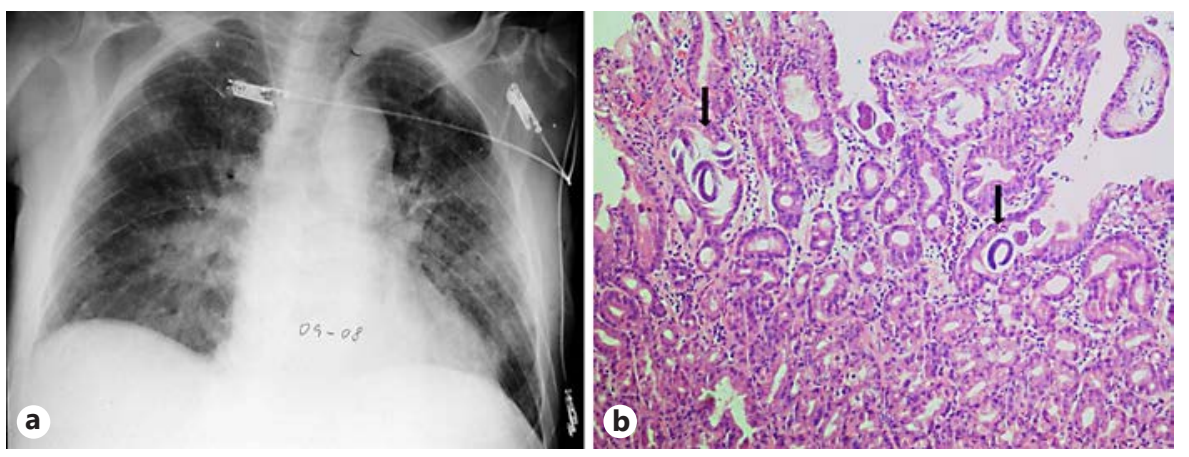

Fig. 2. Strongyloides hyperinfection syndrome in a 77 -year-old male patient originating from Paraguay who presented with rectal bleeding and progressive shortness of breath. The patient had been diagnosed with perinuclear anti-neutrophil cytoplasmic antibodypositive microscopic polyangiitis with rapid progressive glomerulonephritis. In the 4 months prior to admission, he had been treated with two pulse courses of cyclophosphamide and had received daily treatment with prednisolone at a dose of $60 \mathrm{mg} / \mathrm{kg}$. Diffuse bilateral pulmonary infiltrates were present on chest X-ray images (a). Histopathological sections of the stomach mucosa show larvae of Strongyloides stercoralis (arrows) (b). Worms were also visible on microscopic examination of bronchoalveolar lavage fluid and stool specimen. host [88]. Humans can accidentally acquire the infection by ingesting parasite eggs (contaminated food, contact with dogs). In humans, cysts most commonly develop in the liver (70\%) or lungs (20\%), but can also occur in any other organ [89]. The risk factors for acquiring CE are having a rural lifestyle, where there are high populations of free-roaming or stray dogs, poor-quality abattoirs, and animal home slaughtering practices $[87,90]$. The prevalence of $\mathrm{CE}$ increases with age and women are more frequently affected [91].

The incubation period can be highly variable, and cysts can be asymptomatic for years in the absence of complications. Symptoms are related to compression or rupture and are extremely variable according to the cyst localization. Lung hydatid cysts can be an incidental finding at chest X-rays. The presenting signs and symptoms of pulmonary cysts can be nonspecific, such as chronic cough, hemoptysis, dyspnea, and pleuritic chest pain. In case of rupture, the cyst content may be expectorated into the bronchial tree or discharged into the pleural space, with accompanying anaphylactic manifestations. Most of the time, less abrupt ruptures lead to bacterial superinfection and lung abscess [89].

The diagnosis is usually established using imaging studies (X-ray, computed tomography, ultrasound, etc.) and by detecting specific anti-Echinococcus antibodies in serum. The sensitivity for serology in pulmonary CE is 60-84\%, with IgG-ELISA being more sensitive than other methods [92]. The treatment of pulmonary CE is complex, depending on the presentation, and should be conducted in centers with experience. The only radical treat- ment is careful surgical removal of the entire cyst. Watchful observation can be offered for small asymptomatic cysts. Medical treatment alone (albendazole) can be considered for small, uncomplicated pulmonary cysts, but the cure rate is rather low $(<50 \%)$. Antihelminthic therapy should be avoided preoperatively for larger cysts since there is a small risk of leakage/rupture, which would lead to an emergency intervention. Percutaneous aspiration procedures are contraindicated for lung cysts [93].

\section{Strongyloidiasis}

Although not usually a cause of pulmonary disease, Strongyloides stercoralis is a widely distributed soil-transmitted helminth that can establish a lifelong infection if not treated [94]. The prevalence of infection in some regions of Africa and South America can exceed 50\% [95]. In special circumstances such as prolonged corticosteroid treatment or organ transplantation, S. stercoralis can cause a hyperinfection syndrome that can lead to multiorgan failure by invasion of all organs, including the lungs (Fig. 2) [96]. Patients with severe strongyloidiasis can therefore develop acute respiratory distress syndrome and pulmonary hemorrhages, together with bacteremia due to intestinal translocation. Chest X-rays frequently show diffuse shadowing [97], and mortality can be as high as $60 \%$ [96]. Usually, as far as this syndrome is considered, the diagnosis is rather easy because worms can be found in all fluids and secretions (including sputum and bronchoalveolar lavage). In immunocompetent individuals, serology is the most sensitive diagnostic tool (compared to parasitological methods), but its performance is 
much more limited in immunosuppressed patients with malignant strongyloidiasis. The treatment of hyperinfection syndrome consists of daily administration of ivermectin until parasite clearance in the feces, often followed by maintenance therapy with monthly ivermectin. Physicians should be aware of this syndrome, since long-term corticosteroids are prescribed for a wide range of pulmonary conditions. Screening including serology should be performed in patients at risk of developing this syndrome, such as candidates for immunosuppressive treatment and organ transplant who have previously resided in endemic areas [96].

\section{Gnathostomiasis}

Gnathostomiasis, also called larva migrans profundus, is caused predominantly by the nematode (roundworm) Gnathostoma spinigerum. Regions of high endemicity are Japan and Southeast Asia, but its reporting in Central and South America has increased due to the consumption of ceviche (raw fish marinated in lime) [98]. Humans usually become infected with the larvae of Gnathostoma spp. through consumption of raw or inadequately cooked freshwater fish or other intermediate hosts such as snakes, frogs, and chickens. The Gnathostoma larvae are highly invasive and motile and therefore can produce a wide range of symptoms affecting virtually any organ. Migratory cutaneous swellings [99] and eosinophilic meningoencephalitis are the most common and dangerous presentations, but several pulmonary symptoms have been attributed to infection with Gnathostoma spp. as well $[100,101]$. Patients can present with cough, pleuritic chest pain, hemoptysis, lobar consolidation or collapse, pleural effusions, and pneumo- or hydropneumothorax. Most patients present with eosinophilia and eosinophilic pleural effusions. The triad of eosinophilia, subcutaneous swellings, and unexplained eosinophilic pleural effusion with a history of appropriate exposure should raise the suspicion of gnathostomiasis. The diagnosis is made by isolation of the larvae from the lesions, but this is usually not possible for visceral disease. Various serological tests are available, and in Europe the immunoblot detecting specific $24-\mathrm{kDa}$ antigenic bands is mostly used [99]. Albendazole $400 \mathrm{mg}$ twice daily for 21 days is the treatment of choice for pulmonary disease. Ivermectin $200 \mu \mathrm{g} / \mathrm{kg}$ for 2 consecutive days is a valid alternative.

\section{Tropical Pulmonary Eosinophilia}

Tropical pulmonary eosinophilia (Weingarten syndrome) is caused by an immune hyperresponsiveness to microfilariae trapped in the lungs. Since Wuchereria ban- crofti and Brugia malayi are the main etiologies, the syndrome has also been termed "tropical filarial pulmonary eosinophilia." Rarely, a similar hyperresponsive pulmonary syndrome, originally described by Löffler, can be cause by S. stercoralis and Ascaris or Schistosoma spp. [102]. Tropical pulmonary eosinophilia is common on the Indian subcontinent and in Southeast Asia and less frequent in South America and Africa. Males are affected four to seven times more than females [103].

The symptoms can easily be mistaken for asthma, and initial misdiagnosis is very frequent in nonendemic settings [104]. Most commonly cough, breathlessness, wheezing, and chest pain are reported, and symptoms are mostly nocturnal. Fever, weight loss, and fatigue may accompany the respiratory complaints. Evolution towards patchy nonprogressive pulmonary fibrosis is described [103]. Striking eosinophilia of $>3,000 / \mu \mathrm{L}$ that can reach as high as $80,000 / \mu \mathrm{L}$ together with high serum IgE levels is characteristic of tropical pulmonary eosinophilia. Filarial-specific IgE and IgG are markedly raised. The serology for W. bancrofti is positive in 35\% of cases. Paradoxically, search of microfilaria in blood (the usual parasitological method for filarial diagnosis) is always negative, since a few trapped parasites are sufficient to cause a strong immune reaction. Response to a specific treatment with diethylcarbamazine $5 \mathrm{mg} / \mathrm{kg}$ /day for 4 weeks can therefore support the diagnosis. Steroids can be beneficial in case of severe symptoms. One in 5 patients relapses within 5 years [103].

\section{Paragonimiasis}

This lung fluke occurs in Southeast Asia and the Far East as well as in Central and Western Africa [105]. In America, its distribution is limited to Central America and the north of South America. Paragonimus westermani is the species that causes most infections in humans. Humans are only an exceptional host. They become infected by eating raw freshwater crabs and river crayfish which contain infectious metacercariae [106]. Excysted larvae bore through the intestinal wall and migrate to the lungs via the abdominal cavity and diaphragm, where they develop into adult worms. The worms form a cavity 1-4 $\mathrm{cm}$ in diameter. They may also migrate to ectopic sites where they cause eosinophilic abscess. Mild infections are asymptomatic. In the acute stage (invasion and migration of the larvae) there may be diarrhea, abdominal pain, urticaria, and eosinophilia. This is followed by fever, thoracic pain, cough, dyspnea, and malaise. The chronic illness can mimic, as is often misdiagnosed as, tuberculosis with cavitary lesions, presenting mostly with 
recurrent cough and hemoptysis [107] and/or pleural effusion. Incubation can occasionally be extremely long [108]. The diagnosis is made by detection of eggs in sputum with concentration methods (e.g., mix sputum + water + potassium hydroxide, then centrifuge and examine the sediment). Pleural effusions with high eosinophilia can be found [109]. If sputum is swallowed, eggs may also be found in the feces. ELISA testing has a sensitivity and specificity $>90 \%$. Praziquantel $75 \mathrm{mg} /$ day for 3 days or triclabendazole $10 \mathrm{mg} / \mathrm{kg}$ twice on a single day are both very effective treatments (>95\% cure rates) $[110,111]$.

\section{Other Parasites with Occasional Lung Involvement in Migrants}

Acute schistosomiasis, an immune-allergic reaction on Schistosoma larvae (schistosomulae) which may involve the lungs, is almost never seen in immune migrants and will not be developed here. Severe and long-lasting schistosomiasis can lead to PAH related to chronic granulomatous inflammation, followed by scarring fibrosis, around embolized eggs trapped in the pulmonary capillaries. This syndrome may be partly reversible with praziquantel treatment, except when the fibrotic changes are already established at diagnosis. Recently, Italian researchers have identified a new clinical entity related to chronic schistosomiasis, characterized by chronic pulmonary nodules, sometimes symptomatic but usually incidentally diagnosed by chest X-ray, and corresponding to deposition of schistosome eggs [112]. Slow spontaneous cure seems to be the rule, but is accelerated by the administration of praziquantel. It is recommended to consider this condition in the differential diagnosis of chronic pulmonary nodules in (African) migrants since invasive diagnostic procedures can be easily avoided or postponed.

\section{Noncommunicable Chronic Pulmonary Diseases}

\section{Chronic Obstructive Pulmonary Disease}

An estimated 174 million people worldwide have COPD [113]. Increased smoking prevalence in migrants in response to migration-related stress as well as acculturation pressures in the respective host countries [114, 115] can lead to significantly increased airway disease. Smoking-related COPD is well recognized as a major cause of morbidity and mortality worldwide. However, nonsmoking-related COPD is a further entity not commonly encountered in industrialized countries, but prevalent in the context of prolonged biomass smoke exposure. Exposure to indoor smoke from biomass fuels is es- timated to account for $35 \%$ of COPD cases in low- and middle-income countries [116]. It is now increasingly recognized as a distinct small airways disease with different inflammatory phenotype $[117,118]$ and significantly less established emphysema than seen in cigarette smoking-associated COPD. Upper zone predominant bronchial anthracofibrosis is one manifestation that is typically seen in elderly women from rural settings [119]. Water pipe (shisha) smoking, which is more prevalent in some population groups, is also associated with an increased risk of COPD, oral cancer, and lung cancer [120].

\section{ILDs/Lung Scarring}

Environmental and occupational toxin exposures linked to ILDs may have affected some refugees prior to their departure. Prolonged unsafe industrial working practices can lead to unusual and serious disease presentations, sometimes in very young individuals [121-123]. The range of potential hazardous exposures is vast, and a detailed occupational history is paramount. Extensive lung scarring will in many cases be related to previous tuberculosis, often without records of previous effective treatment.

\section{Conclusions}

Respiratory infectious diseases that are uncommon in high-income European countries can be encountered in refugees and migrants originating from regions where these diseases occur sporadically or where they are endemic. Some of these infections are very rare and geographically limited to certain regions, while others, such as strongyloidiasis and echinococcosis, have a wide distribution. Analogous to tuberculosis, some of the organisms can lead to a long-lasting latent or subclinical infection which can progress, even decades after the initial infection, to severe disease in the setting of immunosuppression. Also, noncommunicable diseases can be more prevalent in refugees and can have unusual risk factors. When the diagnosis and treatment of migrant patients with respiratory signs and/ or symptoms is challenging, they should be referred to centers of excellence in order to ensure a correct diagnosis and improved treatment outcome.

\section{Financial Disclosure and Conflicts of Interest}

The study has no funding. The authors have no conflicts of interest to declare.
Olaru/Van Den Broucke/Rosser/Salzer/ Woltmann/Bottieau/Lange 


\section{References}

1 United Nations High Commissioner for Refugees: The UN Refugee Agency. Figures at a Glance. http://www.unhcr.org/figures-at-aglance.html (accessed December 2017).

2 Chan S: How a record number of migrants made their way to Europe. The New York Times, December 22, 2015. https://www. nytimes.com/2015/12/23/world/europe/ migrant-crisis-europe-million.html (accessed December 2017).

3 Eurostat Statistics Explained: Asylum statistics. http://ec.europa.eu/eurostat/statisticsexplained/index.php/Asylum_statistics.

-4 Dara M, Solovic I, Sotgiu G, D’Ambrosio L, Centis R, Tran R, Goletti D, Duarte R, Aliberti S, de Benedictis FM, Bothamley G, Schaberg T, Abubakar I, Teixeira V, Ward B, Gratziou C, Migliori GB: Tuberculosis care among refugees arriving in Europe: a ERS/ WHO Europe Region survey of current practices. Eur Respir J 2016;48:808-817.

5 Lonnroth K, Mor Z, Erkens C, Bruchfeld J, Nathavitharana RR, van der Werf MJ, Lange $\mathrm{C}$ : Tuberculosis in migrants in low-incidence countries: epidemiology and intervention entry points. Int J Tuberc Lung Dis 2017;21: 624-637.

-6 Sotgiu G, Dara M, Centis R, Matteelli A, Solovic I, Gratziou C, Rendon A, Battista Migliori G: Breaking the barriers: migrants and tuberculosis. Presse Med 2017;46:e5-e11.

7 de Smalen AW, Ghorab H, Abd El Ghany M, Hill-Cawthorne GA: Refugees and antimicrobial resistance: a systematic review. Travel Med Infect Dis 2017;15:23-28.

$>8$ Callister ME, Barringer J, Thanabalasingam ST, Gair R, Davidson RN: Pulmonary tuberculosis among political asylum seekers screened at Heathrow Airport, London, 1995-1999. Thorax 2002;57:152-156.

$\checkmark 9$ Lederer I, Taus K, Allerberger F, Fenkart S, Spina A, Springer B, Schmid D: Shigellosis in refugees, Austria, July to November 2015. Euro Surveill 2015;20:30081.

-10 Kocsis E, Savio C, Piccoli M, Cornaglia G, Mazzariol A: Klebsiella pneumoniae harbouring OXA-48 carbapenemase in a Libyan refugee in Italy. Clin Microbiol Infect 2013, 19:E409-E411.

-11 Reinheimer C, Kempf VA, Gottig S, Hogardt M, Wichelhaus TA, O'Rourke F, Brandt C: Multidrug-resistant organisms detected in refugee patients admitted to a University Hospital, Germany June-December 2015 Euro Surveill 2016;21:30110.

$\checkmark 12$ Maltezou HC, Theodoridou M, Daikos GL: Antimicrobial resistance and the current refugee crisis. J Glob Antimicrob Resist 2017; 10: $75-79$.

13 Walter J, Haller S, Hermes J, Arvand M, Abu Sin M, Eckmanns T: Letter to the editor: Is there a need for special treatment of refugees at hospital admission? Euro Surveill 2016;21: 30137.
14 White NJ: Melioidosis. Lancet 2003;361: 1715-1722.

15 Cuadros J, Gil H, Miguel JD, Marabe G, Gomez-Herruz TA, Lobo B, Marcos R, Anda P. Case report: melioidosis imported from West Africa to Europe. Am J Trop Med Hyg 2011 85:282-284

16 Inglis TJ, Rolim DB, Sousa Ade Q: Melioidosis in the Americas. Am J Trop Med Hyg 2006; 75:947-954.

17 Cheng AC, Currie BJ: Melioidosis: epidemiology, pathophysiology, and management. Clin Microbiol Rev 2005; 18:383-416.

18 Currie BJ, Ward L, Cheng AC: The epidemiology and clinical spectrum of melioidosis: 540 cases from the 20 year Darwin prospective study. PLoS Negl Trop Dis 2010;4:e900.

19 Dan M: Melioidosis in travelers: review of the literature. J Travel Med 2015;22:410-414.

20 Currie BJ, Fisher DA, Howard DM, Burrow JN, Selvanayagam S, Snelling PL, Anstey NM, Mayo MJ: The epidemiology of melioidosis in Australia and Papua New Guinea. Acta Trop 2000;74:121-127.

21 Mays EE, Ricketts EA: Melioidosis: recrudescence associated with bronchogenic carcinoma twenty-six years following initial geographic exposure. Chest 1975;68:261-263.

22 Lau SK, Sridhar S, Ho CC, Chow WN, Lee KC, Lam CW, Yuen KY, Woo PC: Laboratory diagnosis of melioidosis: past, present and future. Exp Biol Med (Maywood) 2015;240: $742-751$.

23 Perumal Samy R, Stiles BG, Sethi G, Lim LHK: Melioidosis: clinical impact and public health threat in the tropics. PLoS Negl Trop Dis 2017;11:e0004738.

24 Clark NM, Lynch JP 3rd: Influenza: epidemiology, clinical features, therapy, and preven tion. Semin Respir Crit Care Med 2011;32: 373-392.

25 World Health Organization Regional Office for Europe: Migration and health: key issues. http://www.euro.who.int/en/health-topics/ health-determinants/migration-and-health/ migrant-health-in-the-european-region/migration-and-health-key-issues (accessed January 26, 2018).

26 Fabiani M, Riccardo F, Di Napoli A, Gargiulo L, Declich S, Petrelli A: Differences in influenza vaccination coverage between adult immigrants and Italian citizens at risk for influenza-related complications: a cross-sectional study. PLoS One 2016;11:e0166517.

27 Jimenez-Garcia R, Esteban-Vasallo MD, Rodriguez-Rieiro C, Hernandez-Barrera V, Dominguez-Berjon MA, Carrasco Garrido P, Lopez de Andres A, Cameno Heras M, Iniesta Fornies D, Astray-Mochales J: Coverage and predictors of vaccination against 2012/13 seasonal influenza in Madrid, Spain: analysis of population-based computerized immunization registries and clinical records. Hum Vaccin Immunother 2014;10:449-455.
28 Killingley B, Nguyen-Van-Tam J: Routes of influenza transmission. Influenza Other Respir Viruses 2013;7(suppl 2):42-51.

29 Nicholson KG: Clinical features of influenza. Semin Respir Infect 1992;7:26-37.

30 Muthuri SG, Venkatesan S, Myles PR, Leonardi-Bee J, Al Khuwaitir TS, Al Mamun A, Anovadiya AP, Azziz-Baumgartner E, Baez C, Bassetti M, Beovic B, Bertisch B, Bonmarin I, Booy R, Borja-Aburto VH, Burgmann H, Cao B, Carratala J, Denholm JT, Dominguez SR, Duarte PA, Dubnov-Raz G, Echavarria M Fanella S, Gao Z, Gerardin P, Giannella M, Gubbels S, Herberg J, Iglesias AL, Hoger PH, $\mathrm{Hu}$ X, Islam QT, Jimenez MF, Kandeel A, Keijzers G, Khalili H, Knight M, Kudo K, Kusznierz G, Kuzman I, Kwan AM, Amine IL, Langenegger E, Lankarani KB, Leo YS, Linko R, Liu P, Madanat F, Mayo-Montero E, McGeer A, Memish Z, Metan G, Mickiene A, Mikic D, Mohn KG, Moradi A, Nymadawa P, Oliva ME, Ozkan M, Parekh D, Paul M, Polack FP, Rath BA, Rodriguez AH, Sarrouf EB, Seale AC, Sertogullarindan B, Siqueira MM, Skret-Magierlo J, Stephan F, Talarek E, Tang JW, To KK, Torres A, Torun SH, Tran D, Uyeki TM, Van Zwol A, Vaudry W, Vidmar T, Yokota RT, Zarogoulidis P, Nguyen-VanTam JS: Effectiveness of neuraminidase inhibitors in reducing mortality in patients admitted to hospital with influenza A H1N1pdm09 virus infection: a meta-analysis of individual participant data. Lancet Respir Med 2014;2:395-404.

31 Goeijenbier M, van Genderen P, Ward BJ, Wilder-Smith A, Steffen R, Osterhaus AD: Travellers and influenza: risks and prevention. J Travel Med 2017;24:taw078.

32 Zaki AM, van Boheemen S, Bestebroer TM, Osterhaus AD, Fouchier RA: Isolation of a novel coronavirus from a man with pneumonia in Saudi Arabia. N Engl J Med 2012;367: 1814-1820.

33 Shehata MM, Gomaa MR, Ali MA, Kayali G: Middle East respiratory syndrome coronavirus: a comprehensive review. Front Med 2016;10:120-136

-34 Azhar EI, El-Kafrawy SA, Farraj SA, Hassan AM, Al-Saeed MS, Hashem AM, Madani TA: Evidence for camel-to-human transmission of MERS coronavirus. N Engl J Med 2014;370: 2499-2505.

35 Poletto C, Boelle PY, Colizza V: Risk of MERS importation and onward transmission: a systematic review and analysis of cases reported to WHO. BMC Infect Dis 2016;16:448.

36 Assiri A, Al-Tawfiq JA, Al-Rabeeah AA, AlRabiah FA, Al-Hajjar S, Al-Barrak A, Flemban $\mathrm{H}, \mathrm{Al}-\mathrm{Nassir} \mathrm{WN}$, Balkhy $\mathrm{HH}, \mathrm{Al}-\mathrm{Ha}-$ keem RF, Makhdoom HQ, Zumla AI, Memish ZA: Epidemiological, demographic, and clinical characteristics of 47 cases of Middle East respiratory syndrome coronavirus disease from Saudi Arabia: a descriptive study. Lancet Infect Dis 2013;13:752-761.
Pulmonary Diseases in Refugees and Migrants in Europe 
37 Centers for Disease Control and Prevention: Middle East respiratory syndrome (MERS): interim patient under investigation (PUI) guidance and case definitions. 2016. https:// www.cdc.gov/coronavirus/mers/case-def. html.

- 38 Shalhoub S, Farahat F, Al-Jiffri A, Simhairi R, Shamma O, Siddiqi N, Mushtaq A: IFN- $\alpha 2 a$ or IFN- $\beta 1 \mathrm{a}$ in combination with ribavirin to treat Middle East respiratory syndrome coronavirus pneumonia: a retrospective study. J Antimicrob Chemother 2015;70:2129-2132.

39 World Health Organization: Middle East respiratory syndrome coronavirus: case definition for reporting to WHO. Interim case definition as of 26 July 2017. http://www.who. $\mathrm{int} / \mathrm{csr} /$ disease/coronavirus_infections/case definition/en/ (accessed January 26, 2018).

40 Mo Y, Fisher D: A review of treatment modalities for Middle East respiratory syndrome. J Antimicrob Chemother 2016;71:3340-3350.

41 UNAIDS: Global AIDS update 2016. Geneva, World Health Organization, 2016. http:// www.unaids.org/sites/default/files/media_ asset/global-AIDS-update-2016_en.pdf.

42 World Health Organization: Global tuberculosis report 2017. Geneva, World Health Organization, 2017. http://www.who.int/tb/ publications/global_report/en/ (accessed January 26, 2018).

43 World Health Organization: WHO case definitions of HIV for surveillance and revised clinical staging and immunological classification of HIV-related disease in adults and children. Geneva, World Health Organization, 2006. http://www.who.int/hiv/pub/ guidelines/hivstaging/en/ (accessed January 26, 2018).

-44 Hull MW, Phillips P, Montaner JS: Changing global epidemiology of pulmonary manifestations of HIV/AIDS. Chest 2008;134:12871298.

-45 GBD 2015 HIV Collaborators: Estimates of global, regional, and national incidence, prevalence, and mortality of HIV, 1980-2015: the Global Burden of Disease Study 2015. Lancet HIV 2016;3:e361-e387.

-46 Staitieh B, Guidot DM: Noninfectious pulmonary complications of human immunodeficiency virus infection. Am J Med Sci 2014; 348:502-511.

47 Simonneau G, Gatzoulis MA, Adatia I, Celermajer D, Denton C, Ghofrani A, Gomez Sanchez MA, Krishna Kumar R, Landzberg M, Machado RF, Olschewski H, Robbins IM, Souza R: Updated clinical classification of pulmonary hypertension. J Am Coll Cardiol 2013;62(25 suppl):D34-D41.

48 Correale M, Palmiotti GA, Lo Storto MM, Montrone D, Foschino Barbaro MP, Di Biase M, Lacedonia D: HIV-associated pulmonary arterial hypertension: from bedside to the future. Eur J Clin Invest 2015;45:515-528.
9 Bigna JJ, Nansseu JR, Um LN, Noumegni SR, Sime PS, Aminde LN, Koulla-Shiro S, Noubiap JJ: Prevalence and incidence of pulmonary hypertension among HIV-infected people in Africa: a systematic review and metaanalysis. BMJ Open 2016;6:e011921.

50 Butrous G: Human immunodeficiency virusassociated pulmonary arterial hypertension: considerations for pulmonary vascular diseases in the developing world. Circulation 2015;131:1361-1370.

51 Hoeper MM, Humbert M, Souza R, Idrees M, Kawut SM, Sliwa-Hahnle K, Jing ZC, Gibbs JS: A global view of pulmonary hypertension. Lancet Respir Med 2016;4:306-322.

52 Galie N, Humbert M, Vachiery JL, Gibbs S, Lang I, Torbicki A, Simonneau G, Peacock A, Vonk Noordegraaf A, Beghetti M, Ghofrani A, Gomez Sanchez MA, Hansmann G, Klepetko W, Lancellotti P, Matucci M, McDonagh T, Pierard LA, Trindade PT, Zompatori M, Hoeper M, Aboyans V, Vaz Carneiro A, Achenbach S, Agewall S, Allanore Y, Asteggiano R, Paolo Badano L, Albert Barbera J, Bouvaist H, Bueno H, Byrne RA, Carerj S, Castro G, Erol C, Falk V, FunckBrentano C, Gorenflo M, Granton J, Iung B, Kiely DG, Kirchhof P, Kjellstrom B, Landmesser U, Lekakis J, Lionis C, Lip GY, Orfanos SE, Park MH, Piepoli MF, Ponikowski P, Revel MP, Rigau D, Rosenkranz S, Voller H, Luis Zamorano J: 2015 ESC/ERS Guidelines for the diagnosis and treatment of pulmonary hypertension: the Joint Task Force for the Diagnosis and Treatment of Pulmonary Hypertension of the European Society of Cardiology (ESC) and the European Respiratory Society (ERS): Endorsed by: Association for European Paediatric and Congenital Cardiology (AEPC), International Society for Heart and Lung Transplantation (ISHLT). Eur Heart J 2016;37:67-119.

53 Shiels MS, Cole SR, Kirk GD, Poole C: A meta-analysis of the incidence of non-AIDS cancers in HIV-infected individuals. J Acquir Immune Defic Syndr 2009;52:611-622.

- 54 Marcus JL, Chao C, Leyden WA, Xu L, Yu J, Horberg MA, Klein D, Towner WJ, Quesenberry CP Jr, Abrams DI, Silverberg MJ: Survival among HIV-infected and HIV-uninfected individuals with common non-AIDS-defining cancers. Cancer Epidemiol Biomarkers Prev 2015;24:1167-1173.

55 Shiels MS, Copeland G, Goodman MT, Harrell J, Lynch CF, Pawlish K, Pfeiffer RM, Engels EA: Cancer stage at diagnosis in patients infected with the human immunodeficiency virus and transplant recipients. Cancer 2015; 121:2063-2071.

56 Mugisha JO, Schatz EJ, Randell M, Kuteesa M, Kowal P, Negin J, Seeley J: Chronic disease, risk factors and disability in adults aged 50 and above living with and without HIV: findings from the Wellbeing of Older People Study in Uganda. Glob Health Action 2016;9: 31098.
57 Attia EF, Miller RF, Ferrand RA: Bronchiectasis and other chronic lung diseases in adolescents living with HIV. Curr Opin Infect Dis 2017;30:21-30

58 Queiroz-Telles F, Fahal AH, Falci DR, Caceres DH, Chiller T, Pasqualotto AC: Neglected endemic mycoses. Lancet Infect Dis 2017; 17:e367-e377.

59 Hage CA, Azar MM, Bahr N, Loyd J, Wheat LJ: Histoplasmosis: up-to-date evidencebased approach to diagnosis and management. Semin Respir Crit Care Med 2015;36: 729-745.

-60 Bahr NC, Antinori S, Wheat LJ, Sarosi GA Histoplasmosis infections worldwide: thinking outside of the Ohio River valley. Curr Trop Med Rep 2015;2:70-80.

61 Benedict K, Mody RK: Epidemiology of histoplasmosis outbreaks, United States, 19382013. Emerg Infect Dis 2016;22:370-378.

62 Azar MM, Hage CA: Laboratory diagnostics for histoplasmosis. J Clin Microbiol 2017;55: 1612-1620.

63 Wheat LJ, Freifeld AG, Kleiman MB, Baddley JW, McKinsey DS, Loyd JE, Kauffman CA; Infectious Diseases Society of America: Clinical practice guidelines for the management of patients with histoplasmosis: 2007 update by the Infectious Diseases Society of America. Clin Infect Dis 2007;45:807-825.

64 Shikanai-Yasuda MA, Mendes RP, Colombo AL, Queiroz-Telles F, Kono ASG, Paniago AM, Nathan A, Valle A, Bagagli E, Benard G, Ferreira MS, Teixeira MM, Silva-Vergara ML, Pereira RM, Cavalcante RS, Hahn R, Durlacher RR, Khoury Z, Camargo ZP, Moretti ML, Martinez R: Brazilian guidelines for the clinical management of paracoccidioidomycosis. Rev Soc Bras Med Trop 2017;50: 715-740.

65 Son VT, Khue PM, Strobel M: Penicilliosis and AIDS in Haiphong, Vietnam: evolution and predictive factors of death. Med Mal Infect 2014;44:495-501.

66 Le T, Kinh NV, Cuc NTK, Tung NLN, Lam NT, Thuy PTT, Cuong DD, Phuc PTH, Vinh VH, Hanh DTH, Tam VV, Thanh NT, Thuy TP, Hang NT, Long HB, Nhan HT, Wertheim HFL, Merson L, Shikuma C, Day JN, Chau NVV, Farrar J, Thwaites G, Wolbers M; IVAP Investigators: A trial of itraconazole or amphotericin B for HIV-associated talaromycosis. N Engl J Med 2017;376:23292340.

67 Chang WC, Tzao C, Hsu HH, Lee SC, Huang KL, Tung HJ, Chen CY: Pulmonary cryptococcosis: comparison of clinical and radiographic characteristics in immunocompetent and immunocompromised patients. Chest 2006;129:333-340. 
68 Panel on Opportunistic Infections in HIVInfected Adults and Adolescents: Guidelines for prevention and treatment of opportunistic infections in HIV-infected adults and adolescents: recommendations from the Centers for Disease Control and Prevention, the National Institutes of Health, and the HIV Medicine Association of the Infectious Diseases Society of America. http://aidsinfo.nih.gov/contentfiles/lvguidelines/adult_oi.pdf (accessed December 12, 2017).

69 Perfect JR, Dismukes WE, Dromer F, Goldman DL, Graybill JR, Hamill RJ, Harrison TS, Larsen RA, Lortholary O, Nguyen MH, Pappas PG, Powderly WG, Singh N, Sobel JD, Sorrell TC: Clinical practice guidelines for the management of cryptococcal disease: 2010 update by the Infectious Diseases Society of America. Clin Infect Dis 2010;50:291-322.

-70 Bienvenu AL, Traore K, Plekhanova I, Bouchrik M, Bossard C, Picot S: Pneumocystis pneumonia suspected cases in 604 non-HIV and HIV patients. Int J Infect Dis 2016;46:1117.

-71 Liu Y, Su L, Jiang SJ, Qu H: Risk factors for mortality from Pneumocystis carinii pneumonia (PCP) in non-HIV patients: a meta-analysis. Oncotarget 2017;8:59729-59739.

-72 Maschmeyer G, Helweg-Larsen J, Pagano L, Robin C, Cordonnier C, Schellongowski P; 6th European Conference on Infections in Leukemia (ECIL-6), a joint venture of The European Group for Blood and Marrow Transplantation (EBMT), The European Organization for Research and Treatment of Cancer (EORTC), the International Immunocompromised Host Society (ICHS) and The European LeukemiaNet (ELN): ECIL guidelines for treatment of Pneumocystis jirovecii pneumonia in non-HIV-infected haematology patients. J Antimicrob Chemother 2016;71:2405-2413.

73 Denning DW, Pleuvry A, Cole DC: Global burden of chronic pulmonary aspergillosis as a sequel to pulmonary tuberculosis. Bull World Health Organ 2011;89:864-872.

-74 Oladele RO, Irurhe NK, Foden P, Akanmu AS, Gbaja-Biamila T, Nwosu A, Ekundayo HA, Ogunsola FT, Richardson MD, Denning DW: Chronic pulmonary aspergillosis as a cause of smear-negative TB and/or TB treatment failure in Nigerians. Int J Tuberc Lung Dis 2017;21:1056-1061.

-75 Salzer HJ, Heyckendorf J, Kalsdorf B, Rolling $\mathrm{T}$, Lange C: Characterization of patients with chronic pulmonary aspergillosis according to the new ESCMID/ERS/ECMM and IDSA guidelines. Mycoses 2017;60:136-142.

76 Denning DW, Cadranel J, Beigelman-Aubry C, Ader F, Chakrabarti A, Blot S, Ullmann AJ, Dimopoulos G, Lange C; European Society for Clinical Microbiology and Infectious Diseases and European Respiratory Society: Chronic pulmonary aspergillosis: rationale and clinical guidelines for diagnosis and management. Eur Respir J 2016;47:45-68.
7 Salzer HJF, Lange C, Honigl M: Aspergillus in airway material: ignore or treat? (in German). Internist (Berl) 2017;58:1150-1162.

78 Salzer HJ, Wassilew N, Kohler N, Olaru ID, Gunther G, Herzmann C, Kalsdorf B, Sanchez-Carballo P, Terhalle E, Rolling $\mathrm{T}$, Lange C, Heyckendorf J: Personalized medicine for chronic respiratory infectious diseases: tuberculosis, nontuberculous mycobacterial pulmonary diseases, and chronic pulmonary aspergillosis. Respiration 2016; 92:199-214.

79 Kirk MD, Pires SM, Black RE, Caipo M, Crump JA, Devleesschauwer B, Dopfer D, Fazil A, Fischer-Walker CL, Hald T, Hall AJ, Keddy KH, Lake RJ, Lanata CF, Torgerson PR, Havelaar AH, Angulo FJ: World Health Organization estimates of the global and regional disease burden of 22 foodborne bacterial, protozoal, and viral diseases, 2010: a data synthesis. PLoS Med 2015;12:e1001921.

80 Haque R, Huston CD, Hughes M, Houpt E, Petri WA Jr: Amebiasis. N Engl J Med 2003; 348:1565-1573

81 Martinez-Giron R, Esteban JG, Ribas A, Doganci L: Protozoa in respiratory pathology: a review. Eur Respir J 2008;32:1354-1370.

82 Ibarra-Perez C: Thoracic complications of amebic abscess of the liver: report of 501 cases. Chest 1981;79:672-677.

83 Nwafo DC, Egbue MO: Intrathoracic manifestations of amoebiasis. Ann R Coll Surg Engl 1981;63:126-128.

84 Stanley SL Jr: Amoebiasis. Lancet 2003;361: 1025-1034.

-85 Torgerson PR, Devleesschauwer B, Praet N, Speybroeck N, Willingham AL, Kasuga F, Rokni MB, Zhou XN, Fevre EM, Sripa B, Gargouri N, Furst T, Budke CM, Carabin H, Kirk MD, Angulo FJ, Havelaar A, de Silva N: World Health Organization estimates of the global and regional disease burden of 11 foodborne parasitic diseases, 2010: a data synthesis. PLoS Med 2015;12:e1001920.

86 Craig PS, McManus DP, Lightowlers MW, Chabalgoity JA, Garcia HH, Gavidia CM, Gilman RH, Gonzalez AE, Lorca M, Naquira C, Nieto A, Schantz PM: Prevention and control of cystic echinococcosis. Lancet Infect Dis 2007:7:385-394.

-87 Deplazes P, Rinaldi L, Alvarez Rojas CA, Torgerson PR, Harandi MF, Romig T, Antolova D, Schurer JM, Lahmar S, Cringoli G, Magambo J, Thompson RC, Jenkins EJ: Global distribution of alveolar and cystic echinococcosis. Adv Parasitol 2017;95:315-493.

88 Agudelo Higuita NI, Brunetti E, McCloskey C: Cystic echinococcosis. J Clin Microbiol 2016;54:518-523.

89 Eckert J, Gemmell MA, Meslin FX, Pawłowski ZS (eds): WHO/OIE Manual on Echinococcosis in Humans and Animals: A Public Health Problem of Global Concern. Paris/Geneva, World Organisation for Animal Health (Office International des Epizooties)/World Health Organization, 2001.
90 Possenti A, Manzano-Roman R, SanchezOvejero C, Boufana B, La Torre G, Siles-Lucas M, Casulli A: Potential risk factors associated with human cystic echinococcosis: systematic review and meta-analysis. PLoS Negl Trop Dis 2016;10:e0005114.

91 Craig PS, Li T, Qiu J, Zhen R, Wang Q, Giraudoux $\mathrm{P}$, Ito $\mathrm{A}$, Heath $\mathrm{D}$, Warnock $\mathrm{B}$, Schantz P, Yang W: Echinococcosis and Tibetan communities. Emerg Infect Dis 2008; 14:1674-1675.

92 Zarzosa MP, Orduna Domingo A, Gutierrez P, Alonso P, Cuervo M, Prado A, Bratos MA, Garcia-Yuste M, Ramos G, Rodriguez Torres A: Evaluation of six serological tests in diagnosis and postoperative control of pulmonary hydatid disease patients. Diagn Microbiol Infect Dis 1999;35:255-262.

93 Brunetti E, Kern P, Vuitton DA; Writing Panel for the WHO-IWGE: Expert consensus for the diagnosis and treatment of cystic and alveolar echinococcosis in humans. Acta Trop 2010;114:1-16.

-94 Prendki V, Fenaux P, Durand R, Thellier M, Bouchaud O: Strongyloidiasis in man 75 years after initial exposure. Emerg Infect Dis 2011;17:931-932.

95 Schar F, Trostdorf U, Giardina F, Khieu V, Muth S, Marti H, Vounatsou P, Odermatt P. Strongyloides stercoralis: global distribution and risk factors. PLoS Negl Trop Dis 2013; 7:e2288.

-96 Buonfrate D, Requena-Mendez A, Angheben A, Munoz J, Gobbi F, Van Den Ende J, Bisoffi Z: Severe strongyloidiasis: a systematic review of case reports. BMC Infect Dis 2013;13:78.

-97 Nabeya D, Haranaga S, Parrott GL, Kinjo T, Nahar S, Tanaka T, Hirata T, Hokama A, Tateyama M, Fujita J: Pulmonary strongyloidiasis: assessment between manifestation and radiological findings in 16 severe strongyloidiasis cases. BMC Infect Dis 2017;17: 320.

98 Moore DA, McCroddan J, Dekumyoy P, Chiodini PL: Gnathostomiasis: an emerging imported disease. Emerg Infect Dis 2003;9: 647-650.

-99 Bussaratid V, Dekumyoy P, Desakorn V, Jaroensuk $\mathrm{N}$, Liebtawee $\mathrm{B}$, Pakdee $\mathrm{W}$, Wattanagoon Y: Predictive factors for Gnathostoma seropositivity in patients visiting the Gnathostomiasis Clinic at the Hospital for Tropical Diseases, Thailand during 20002005. Southeast Asian J Trop Med Public Health 2010;41:1316-1321.

100 Prijyanonda B, Pradatsundarasar A, Viranuvatti V: Pulmonary gnathostomiasis; a case report. Ann Trop Med Parasitol 1955;49: 121-122.

101 Nitidandhaprabhas P, Hanchansin S, Vongsloesvidhya Y: A case of expectoration of Gnathostoma spinigerum in Thailand. Am J Trop Med Hyg 1975;24:547-548.
Pulmonary Diseases in Refugees and Migrants in Europe 
102 Rocha A, Dreyer G, Poindexter RW, Ottesen EA: Syndrome resembling tropical pulmonary eosinophilia but of non-filarial aetiology: serological findings with filarial antigens. Trans R Soc Trop Med Hyg 1995;89: 573-575.

103 Mullerpattan JB, Udwadia ZF, Udwadia FE: Tropical pulmonary eosinophilia - a review. Indian J Med Res 2013;138:295-302.

104 Boggild AK, Keystone JS, Kain KC: Tropical pulmonary eosinophilia: a case series in a setting of nonendemicity. Clin Infect Dis 2004;39:1123-1128.

105 Keiser J, Utzinger J: Food-borne trematodiases. Clin Microbiol Rev 2009;22:466-483.

-106 Nagayasu E, Yoshida A, Hombu A, Horii Y, Maruyama H: Paragonimiasis in Japan: a twelve-year retrospective case review (20012012). Intern Med 2015;54:179-186.

107 Im JG, Kong Y, Shin YM, Yang SO, Song JG, Han MC, Kim CW, Cho SY, Ham EK: Pulmonary paragonimiasis: clinical and experimental studies. Radiographics 1993;13:575586.

108 Meehan AM, Virk A, Swanson K, Poeschla EM: Severe pleuropulmonary paragonimiasis 8 years after emigration from a region of endemicity. Clin Infect Dis 2002;35:87-90.

109 Hwang KE, Song HY, Jung JW, Oh SJ, Yoon KH, Park DS, Jeong ET, Kim HR: Pleural fluid characteristics of pleuropulmonary paragonimiasis masquerading as pleural tuberculosis. Korean J Intern Med 2015;30: 56-61.

110 Calvopina M, Guderian RH, Paredes W, Chico M, Cooper PJ: Treatment of human pulmonary paragonimiasis with triclabendazole: clinical tolerance and drug efficacy. Trans R Soc Trop Med Hyg 1998;92:566569.
111 Calvopina M, Guderian RH, Paredes W, Cooper PJ: Comparison of two single-day regimens of triclabendazole for the treatment of human pulmonary paragonimiasis. Trans R Soc Trop Med Hyg 2003;97:451454.

112 Gobbi F, Buonfrate D, Angheben A, Beltrame A, Bassetti M, Bertolaccini L, Bogina G, Caia S, Duranti S, Gobbo M, Marchese V, Marocco S, Merelli M, Monteiro G, Terzi A, Bisoffi Z: Pulmonary nodules in African migrants caused by chronic schistosomiasis. Lancet Infect Dis 2017;17:e159-e165.

113 GBD 2015 Chronic Respiratory Disease Collaborators: Global, regional, and national deaths, prevalence, disability-adjusted life years, and years lived with disability for chronic obstructive pulmonary disease and asthma, 1990-2015: a systematic analysis for the Global Burden of Disease Study 2015. Lancet Respir Med 2017;5:691-706.

114 Jawad M, Khader A, Millett C: Differences in tobacco smoking prevalence and frequency between adolescent Palestine refugee and non-refugee populations in Jordan, Lebanon, Syria, and the West Bank: cross-sectional analysis of the Global Youth Tobacco Survey. Confl Health 2016;10:20.

115 Tami-Maury I, Aigner CJ, Rush S, Hong JH, Strom SS, Prokhorov AV, Gritz ER: The association of smoking with English and Spanish language use as a proxy of acculturation among Mexican-Americans. J Immigr Minor Health 2017;19:1156-1162.
116 Lopez AD, Mathers CD, Ezzati M, Jamison DT, Murray CJL: Global burden of disease and risk factors. Washington, The World Bank, 2006.

117 Liu S, Zhou Y, Wang X, Wang D, Lu J, Zheng J, Zhong N, Ran P: Biomass fuels are the probable risk factor for chronic obstructive pulmonary disease in rural South China. Thorax 2007;62:889-897.

118 Zhao D, Zhou Y, Jiang C, Zhao Z, He F, Ran $P$ : Small airway disease: a different phenotype of early stage COPD associated with biomass smoke exposure. Respirology 2018; 23:198-205.

119 Golpe R, Martin-Robles I, Sanjuan-Lopez P, Perez-de-Llano L, Gonzalez-Juanatey C, Lopez-Campos JL, Arellano-Orden E: Differences in systemic inflammation between cigarette and biomass smoke-induced COPD. Int J Chron Obstruct Pulmon Dis 2017;12: 2639-2646.

120 Waziry R, Jawad M, Ballout RA, Al Akel M, Akl EA: The effects of waterpipe tobacco smoking on health outcomes: an updated systematic review and meta-analysis. Int J Epidemiol 2017;46:32-43.

121 Barmania S: Deadly denim: sandblasting-induced silicosis in the jeans industry. Lancet Respir Med 2016;4:543.

122 Alaya Z, Kalboussi H, Osman W, Naouar N, Zeglaoui H, Bouajina E: Silica-associated systemic sclerosis occurring after an occupational exposure to arc welding (in French). Pan Afr Med J 2016;25:70.

123 Gothi D, Gahlot T, Sah RB, Saxena M, Ojha UC, Verma AK, Spalgais S: Asbestos-induced lung disease in small-scale clutch manufacturing workers. Indian J Occup Environ Med 2016;20:95-102. 